\title{
THE CHARACTERISTICS OF NUTMEG (MYRISTICA FRAGRANS HOUTT) GROWTH USING AGROFORESTRY SYSTEM IN TERNATE ISLAND, INDONESIA
}

\author{
Tjokrodiningrat $\mathbf{S}$. \\ Faculty of Agriculture, University of Khairun, Indonesia \\ Ashari S., Syekhfani S., Aini N. \\ Faculty of Agriculture, University of Brawijaya, Indonesia \\ *E-mail: spiceternate@gmail.com
}

\begin{abstract}
Nutmeg (Myristica spp.) is a high economic value spice crops which is spread on the whole area of Ternate Island, North Maluku province. Nutmeg is generally cultivated using agroforestry system with many varieties of populations and species which is supposed to influence the characteristics of nutmeg plants and micro climate. Thus, understanding the plant characteristics and microclimate of nutmeg plantation using agroforestry system is very important. Nutmeg plantation using agroforestry system is a mix between nutmeg as the main crop with other crops such as cloves, coconut and others. The focus of this research is to understand the characteristics of nutmeg, especially crop production components which cover the number and weight of seeds, microclimate as well as variations of population and diversity. This research employed observation method in which the sample was purposively set as many as 30 plants, using point-centered quarter sampling method. The results showed that agroforestry system affect the characteristics of nutmeg plants and the microclimate. The optimum plant population of 200 plants ha- 1 with diversity of 1.38 , had higher number and seed weight target $^{-1}$ than the population of 100 plants ha ${ }^{-1}$ with diversity of 0.78 or population of 300 plants ha ${ }^{-1}$ with diversity of 0.82 .
\end{abstract}

\section{KEY WORDS}

Nutmeg, production, plant characteristics, agroforestry, microclimate.

North Maluku Province, Indonesia, has long been known to the world as the center of nutmeg production, an indigenous plantation plant. Parts of nutmeg which have high economic values are seeds and mace because they can produce oil, grease, terpenoids and aroma (Bustaman, 2007). In Ternate Island, nutmeg is generally cultivated using agroforestry system in people plantation by mixing nutmeg as the main crop with other crops such as cloves, coconut, betel nut, jackfruit, durian, linggua, banana and others. Nutmeg plantation using agroforestry system in Ternate Island reaches around 3.616 ha where nutmeg as the main crop grown together with other crops on the same land (mixed-planting) with variety of populations and diversities of species per unit area. Variation of populations and diversity of plant species in an agroforestry system relatively affect crop production (Belote et al., 2011), in the form of facilitation, competition or neutral (Futakuchi 2007; Umrani and Jain, 2010) based on the availability of space and the use of resources, which in turn it is expressed through the characters of the plants such as branch, canopy and economic value (He et al., 2005; Khorshidi, et al., 2009; Tjokrodiningrat, et al., 2013; Pretzsch, 2014; Cinar and Tug, 2015; Di Zhang, 2015).

Nutmeg crop production in Ternate island is generally low and the variation among plantations is wide enough, ranges from $0: 10$ to $0: 43$ tons ha ${ }^{-1} \mathrm{yr}^{-1}$, similar to $1500-3000$ trees $^{-1}$ year $^{-1}$ (Hadad, 2009; Tjokrodiningrat, et al . , 2011). The potential of nutmeg production reaches 5000 pieces per tree, at twice great harvest season in a year and the year-round production ( Hadad , 2009; Marzuki, et.al., 2006; Thankamani et al. 1994). This condition recently becomes the concern of government and the nutmeg businessman (Tjokrodiningrat et al., 2011; Abdul-Madiki and Tjokrodiningrat, 2013). Productivity gap between locations is suspected to be related to population and diversity in every plantation. 
Various studies revealed that agroforestry system in tropical area can be more productive than monocultures when the resources are optimally used (Michon et al., 1986; Cannell, 1991; Jin et al., 2009), due to the ability of agroforestry system in modifying the microclimate and protecting plants from strong winds as well as the contribution of its diversity to soil fertility and availability of nutrients such as nitrogen $(N)$, phosphorus $(P)$, potassium (K), carbon (C), soil acidity and production (Ong, 1991; Jin et al ., 2008; Rodriguez et al., 2011; Sumantra, 2012). Diversity can have positive effect on plants, although the population size and diversity of plants on an areal can lead to competition or otherwise facilitates the plant to modify themselves and the nature of symmetry (Ditzer et al., 2000; Weiner et al., 2001; Berger et al., 2007; Enquist et al., 2009; Damgaard, 2011; Pretzsch, 2014) depending on the resources condition, especially the number of nutrient and light (Kohli et al, 2008). Population and diversity, thus, at a certain level are able to deliver optimum results (Fangliang and Duncan, 2000; Wright, 2002; Ariapour and Afrougheh. 2008; Onrizal, 2009) and are expressed on the characters of the plant and production (He et al., 2005; Poorter and Bongers, 2006; Wardiana et al., 2008; Xu, 2009), as a response to population for both intra- and interspecific (Beland et al., 2003), which is controlled by the nature of plants, the ability of individual interactions, and the adaptability of plants (Berger et al., 2007; Makinde, 2009; Chalmers, 2014). The population becomes limit when there is overlap between canopy which indicates competition as expressed through plant performance (Wyxzomirski and Weiner, 2009).

Although there are many theories about population variation and diversity, the absence of data and information on the agro-ecological conditions of nutmeg plantation using agroforestry system limits researchers in underlying and generalizing the problem. Therefore, this study is very important to understand the characteristics of the nutmeg crop and the microclimate of the plantation in Ternate Island. This study objectively analyzed the condition of nutmeg agroforestry system based on population size and species diversity which made up a third of the plantation system, with a focus on the characteristics of nutmeg plants and micro climate. The results of analysis on each nutmeg plantation were used as a basis for resolving nutmeg crop production range problems.

\section{METHODS OF RESEARCH}

Location and Time. The study was conducted on a nutmeg plantation in Sulamadaha, Ngade, and Fitu Puncak Village, Ternate Island, North Maluku Province, at an altitude of 57$358 \mathrm{~m}$ above sea level. The location is at the coordinates of 127'20'51 "- 127'20'55" East Longitude and 0.46 '16 "- 0.46'21" North Latitude. Nutmeg plantation lies on an area with andisols and inceptisols soil type (Soil Survey Staff, 1999), pH 5.3-5.6 (Laboratory of Soil, Faculty of Agriculture, Brawijaya University, 2015). The Nutmeg plantation has variety of populations and plant species with Myristica fragrans Houtt type as the main crop. This kind of plantation has over half number of nutmeg plants from the total of all plant types. The research was conducted in two (2) phases. First, observation which was conducted in three districts of Ternate island for determining the location and samples. This observation was held from July to August 2013. Second, plant characteristics and microclimate measurement and analysis which lasted from October 2014 to June 2015.

Samples Choice. Each location consists of plantation crops, horticultural crops and forest plants which are dominated by productive nutmeg plants, Myristica fragrans, aged 2060 years based on the classification of Marcelle (1995) and Hadad et al., (1991; 2006; 2009). Nutmeg plantation using agroforestry system under study is described in terms of population and species diversity. The population consisted of plant density and diversity $\left(\mathrm{H}^{\prime}\right)$, as the number of species in a plant community, calculated using survey applying the system of ArcGIS (Arc-Info / Arc-View version 3.2). All trees with diameters of $\geq 10 \mathrm{~cm}$ at the height of 1.5 $\mathrm{m}$ were calculated and recorded. Based on these calculations, data in each location was analyzed to determine the density, diversity, relative density and relative dominance (data was not shown) based on the method used by Arrijani (2008). Diversity was calculated using Shannon dominance index in Elzinga (1988), as follows: 


$$
H^{\prime}=\frac{n \log _{n} n-\Sigma f_{i} \log _{n} f_{i}}{n}(1) \text {, }
$$

Where: $n=$ total number of plants, $f_{i}=$ number of plants in every species, and $\log _{n}=$ natural logarithm.

Calculation of population size was used as a basis to determine three plantation categories which represent the general condition of nutmeg agroforestry system in Ternate Island. The three categories of the population were 100, 200, and 300 trees ha ${ }^{-1}$. Then, the diversity in each population category was analyzed. The obtained indices of diversity in a population of 100,200 , and 300 were respectively $0.78,1.38$, and 0.82 (Shannon index). The three locations have different cluster type plant distribution pattern. Representation of the three categories were defined in Ngade village with population of 100 trees ha ${ }^{-1}$ and diversity of $0.78\left(\mathrm{Agf}_{1}\right)$, in Sulamadaha village with population of 200 trees ha ${ }^{-1}$ and diversity of $1.38\left(\mathrm{Agf}_{2}\right)$, and Fitu village with population of 300 trees ha ${ }^{-1}$ and diversity of $0.82\left(\mathrm{Agf}_{3}\right)$

Nutmeg samples were choosen purposively in which each study site consists of 10 trees per hectare, so that there were 30 samples of nutmeg trees used in this study. Each sample plant was observed in five microclimate points; four points at the east-west-northsouth boundary of canopy and 1 point outside the canopy. Thus, there were 50 observation points at each location and total 150 observation points. A tree was also choosen as the central point using Point-Centered Quarter sampling method (Elzinga, 1988) with the help of line transects made on each nutmeg plantation. Transect line was made by drawing a line from north to south along $100 \mathrm{~m}$ with each transect line parallel to each other. In addition, two plots at $30 \mathrm{~m} \times 30 \mathrm{~m}$ size were randomly created in each transect line. In the plot, the "central point" nutmeg was choosen. Plant character measurement was carried out on the central point sample and other plants in the plot.

Nutmeg Plant Characteristics and Microclimate. Plant characterization was conducted using phenotypic characteristics in IPGRI guideline (1980) as a descriptor record, expressed throughout the environment, and can be easily seen using eyes. Nutmeg plant characters were observed by measuring the following variables: Diameter Breast Height $(\mathrm{DBH}, \mathrm{cm})$, was known by measuring the trunk girth (LB) at $130 \mathrm{~cm}$ height from the base of the trunk $\left(\mathrm{DBH}_{130 \mathrm{~cm}}\right)$ (Pretzsch, 2009; Mitchell, 2010); Basal area $\left(\mathrm{BA}_{1.3}, \mathrm{~cm}^{2}\right)$, was calculated based on the $\mathrm{DBH}$ using the equation of $\mathrm{BA}=\mathrm{DBH}^{2} \times \pi / 4$ (Anonymous, 2004; Pretzsch, 2009); Number of branches $(\mathrm{Bn})$, were known by calculating all primary branches with a diameter of $\geq 5 \mathrm{~cm}$ in a tree; Width of canopy $(\mathrm{m})$, was measured based on the projection of tree crown on the east-west and north-south sides (Pretzsch, 2009); Height of tree (Ph, m), was known by measuring the distance of the stem to the top of the tallest tree directly using a roll meter; Leaf area index (LAI), was measured using a portable LAl-2000 plant canopy analyzer (Licor, USA). LAl measurement methods used were according to Mitchell, (2010) and Early and Wan-Isaac, (2008); Leaf chlorophyll index ( $\mathrm{LCl}$ ), was measured using a Minolta SPAD-502 leaf chlorophyll meter, following the method used by Liu and Yang (2012); Nutmeg production, ie the number of fruit (seeds of tree $\mathrm{yr}^{-1}$ ) and fruit weight $\left(\mathrm{kg} \mathrm{tree}^{-1} \mathrm{yr}^{-1}\right)$, was calculated per harvest time per tree at each harvest peak season. Fruit weighing was performed twice. First, the whole fruit was weighed along with the flesh of the fruit. Second, seeds were weighed with the maces which had been removed from the flesh of the fruit. The fruits ready for harvest were characterized by the split of some fruits in a tree, or the split of a fruit on a particular branch/twig/shoot.

Microclimate was measured inside and outside the plant samples in the components as follows: Solar radiation was measured using a digital lux meter AR813A; temperature $\left({ }^{\circ} \mathrm{C}\right)$ and humidity (\%) were measured using temperature and clock humidity HTC-1, measurements were taken at four points under the plant canopy, $0.5 \mathrm{~m}$ inside the line from outer crown projection at the height of $130 \mathrm{~cm}$ from soil surface, and at an open space outside the canopy at the same height. Measurement of solar radiation under the canopy $\left(R_{1}\right)$ and the radiation in the open space outside the canopy $\left(R_{2}\right)$ were performed to 
determine the amount of radiation being held by the canopy $\left(R_{n}\right)$, where $R_{n}=R_{2}-R_{1}$. Intercept radiation value was calculated using the equation used by Sumantra et al., (2012):

$$
I_{i}=\frac{I_{0}-I_{u}}{I_{0}} \times 100 \%
$$

where $I_{i}$ is intercepted radiation, $I_{o}$ is the intensity of radiation under the canopy, and $I_{u}$ is the intensity of radiation outside the canopy.

Radiation Use Efficiency (RUE , g / W m - 2) was calculated based on the relationship between the radiation intercepted by the plants $\left(I_{i}\right)$ with above-ground biomass (ABG) (Rudorff et al., 1996), as follows : RUE $=A B G / I_{i}$. The biomass was estimated based on the dry seeds weight on the three nutmeg plantations, using allometric equation according to Sutaryo (2009) which was derived from the equation $Y=a X^{b}$ into $Y=\log a+b(\log X)$, resulted on nutmeg biomass equation $Y=2.7931+0.8238(\log X)$, so that:

$$
\text { RUE }=Y / l i
$$

Rainfall $(\mathrm{mm})$ was measured using rainfall measuring tool of modified ombrometer. The tool was placed in the open space within a half of the tree's height nearby, a night before the measurement. The Measurements were made every morning at 07.00 a.m.

Data analysis. To determine the effect of agroforestry systems (population and diversity) on nutmeg plant characteristics and microclimates, analysis of variance (ANOVA) was applied. When there is an effect, means different test using Duncan range test at the level of significance $\alpha=0.05$ is applied. Coefficients of variation (CV, \%) was analyzed as an indicator of variability. The relationship between agroforestry plantation with nutmeg crop characteristics and microclimates was analized using correlation and simple regresion. To estimate the contribution of population, diversity and micro climate component to nutmeg crop production targets, stepwise procedure multiple linear regression method was applied (Sarle and Goodninght, 1982). To determine the maximum population, quadratic regression method was used. The data analysis was conducted using SAS ver. 9.1 (SAS, 2004).

\section{RESULTS AND DISCUSSION}

Characteristics of nutmeg plants at plantation using agroforestry system. Analysis of variance showed a significant effect of populations and diversity in the three nutmeg plantations using agroforestry system on the characters of nutmeg plants, namely branch number $(\mathrm{Bn})$, leaf chlorophyll index ( $\mathrm{LCl})$, seed number target ${ }^{-1}(\mathrm{Snt})$, seed weight target $^{-1}$ (Swt), DBH total (DBHp), BA targets (tree) (Bat), BA total (BAp), ILD, canopy width (CWd), but not including the plant height (Table 1). Duncan Range test showed that the most/biggest number of branches, $\mathrm{DBH}$ target (tree) $(\mathrm{DBHt})$, total $\mathrm{DBH}$, total $\mathrm{BA}$ and canopy width were found in agroforestry systems with 100 plants population ha-1 with diversity of $0.78\left(\right.$ Agf $\left._{1}\right)$ and it was significantly different with agroforestry system with 300 plants population ha- 1 with a diversity of $0.82\left(\mathrm{AgF}_{2}\right)$. The highest leaf chlorophyll Index, number of $\mathrm{s}^{-1}$, seed weight target-1, trees BA, number of branches and leaf area index were found in plabtation using agroforestry system with population of 200 plants ha ${ }^{-1}$ with diversity of $1: 38\left(\mathrm{AgF}_{2}\right)$ which was significantly different with $\mathrm{Agf}_{1}$ and $\mathrm{Agf}_{3}$ (see Table 2).

The effect of agroforestry systems based on population and diversity showed plant characters variations in particular seed number target ${ }^{-1}$, seed weight target ${ }^{-1}$, branches number, canopy width and leaf chlorophyll index. Plantations with population of 200 trees ha ${ }^{-1}$ with diversity of 1.38 was the most optimum on seed number target ${ }^{-1}$ and seed weight target $^{-1}$. In addition, the effect of population and diversity was seen at the branches number, leaf chlorophyll index, BA tree ${ }^{-1}$ and leaf area index. The population of 200 trees ha $^{-1}$ with a diversity of $1.38\left(\mathrm{Agf}_{2}\right)$, was therefore considered to be more optimum to the plant character compared to the other two populations and diversities $\left(\mathrm{Agf}_{1}\right.$ and $\left.\mathrm{Agf}_{3}\right)$. 
Table 1 - Analysis of variance of the effect of plant population and diversity on the characters of the nutmeg plants in nutmeg plantations using agroforestry systems

\begin{tabular}{|c|c|c|c|c|c|c|}
\hline Variable & Mean & Variation Coefficient & Std Dev & Minimum & Maximum & $\mathrm{P}>\mathrm{F}$ \\
\hline Seed number target $^{-1}$ & 5590 & 34.293 & 4703 & 598.00000 & 16273 & $<.0001^{\text {hs }}$ \\
\hline Seed weight target ${ }^{-1}$ & 16732 & 18.964 & 15577 & 1203 & 52267 & $<.0001^{\mathrm{hs}}$ \\
\hline Leaf chlorophyl index & 36.04400 & 9.375 & 4.04908 & 29.78000 & 44.85000 & $0.0013^{\mathrm{hs}}$ \\
\hline Leaf area index & 49.21167 & 19.385 & 13.3700 & 32.56000 & 76.53000 & $0.0028^{\mathrm{hs}}$ \\
\hline Basal area target $^{-1}$ & 606.5180 & 14.067 & 103.846 & 360.1400 & 786.1400 & $0.0052^{\mathrm{hs}}$ \\
\hline Basal area total & 2548 & 29.135 & 943.366 & 1413 & 5685 & $0.0006^{\mathrm{hs}}$ \\
\hline $\mathrm{DBH}_{\text {target }}{ }^{-1}$ & 29.75367 & 17.116 & 5.80586 & 24.52000 & 46.18000 & $0.0171^{\mathrm{s}}$ \\
\hline $\mathrm{DBH}$ total & 720.5540 & 37.844 & 305.098 & 472.0500 & 1674 & $0.0262^{s}$ \\
\hline Canopy width & 10.05467 & 18.648 & 2.17301 & 6.15000 & 15.67000 & $0.0079^{\mathrm{hs}}$ \\
\hline Branch number & 76.63333 & 26.594 & 29.1789 & 29.00000 & 160.0000 & $<.0001^{\mathrm{hs}}$ \\
\hline Plant high & 14.02700 & 22.449 & 3.20797 & 9.64000 & 24.80000 & $0.2513^{\mathrm{ns}}$ \\
\hline
\end{tabular}

Note: $n s=$ non significant, $s=$ significant, and $h s=$ highly significant at level $\alpha=0.05$.

Table 2 - The effect of plant population and diversity on nutmeg morphological characteristics

\begin{tabular}{llllllllllll}
\hline $\begin{array}{l}\text { Nutmeg } \\
\text { Plantation }\end{array}$ & $\mathrm{Ph}$ & $\mathrm{Bn}$ & $\mathrm{LCl}$ & Snt & SWt & DBHt & DBHp & BAt & BAp & LAI & CWd \\
\hline Agf $_{1}$ & $15.107 \mathrm{a}$ & $62.1 \mathrm{~b}$ & $36.863 \mathrm{~b}$ & $4214 \mathrm{~b}$ & $12561 \mathrm{~b}$ & $33.729 \mathrm{a}$ & $916.0 \mathrm{a}$ & $523.81 \mathrm{~b}$ & $3462 \mathrm{a}$ & $49.808 \mathrm{a}$ & $11.702 \mathrm{a}$ \\
$\mathrm{Agf}_{2}$ & $14.265 \mathrm{a}$ & $108.5 \mathrm{a}$ & $38.921 \mathrm{a}$ & $10649 \mathrm{a}$ & 32.123a & $28.987 \mathrm{~b}$ & $691.5 \mathrm{~b}$ & $656.93 \mathrm{a}$ & $2202 \mathrm{~b}$ & $57.576 \mathrm{a}$ & $9.697 \mathrm{~b}$ \\
$\mathrm{Agf}_{3}$ & $12.709 \mathrm{a}$ & $59.3 \mathrm{c}$ & $32.348 \mathrm{c}$ & $1908 \mathrm{Dc}$ & $5513 \mathrm{c}$ & $26.545 \mathrm{~b}$ & $554.1 \mathrm{~b}$ & $638.82 \mathrm{a}$ & $1979 \mathrm{c}$ & $40.251 \mathrm{~b}$ & $8.765 \mathrm{c}$ \\
\hline
\end{tabular}

Note: Means with the same letters within columns indicate significant differences at the Duncan 0.05

$\mathrm{Agf}_{1}=$ plantation with agroforestriy system with population of 100 trees ha ${ }^{-1}$ with diversity of 0.78

$\mathrm{Agf}_{2}=$ plantation with agroforestriy system with population of 200 trees ha ${ }^{-1}$ with diversity of 1.38

$\mathrm{Agf}_{3}==$ plantation with agroforestriy system with population of 300 tress ha ${ }^{-1}$ with diversity of 0.82

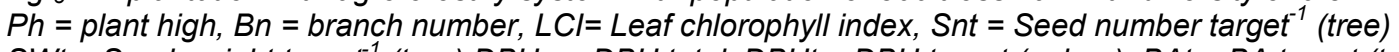

$S W t=$ Seed weight target ${ }^{-1}$ (tree) $D B H p=D B H$ total, $D B H t=D B H$ target (pohon), BAt = BA target (tree)

$B A p=B A$ total, $L A l=$ Leaf area index,$C W d=$ Canopy width

Table 3 - Stepwise procedure summary and the optimum model of morphological characteristic based on agroforestry systems of nutmeg plantation

\begin{tabular}{|c|c|c|c|c|c|c|}
\hline $\begin{array}{l}\text { Nutmeg Morphological } \\
\text { Characteristics }\end{array}$ & $\begin{array}{l}\text { Variable } \\
\text { entered }\end{array}$ & $\begin{array}{l}\text { Number of } \\
\text { Variabel In }\end{array}$ & $\begin{array}{l}\text { Partial } \\
\text { R-square }\end{array}$ & $\begin{array}{l}\text { Model } \\
\text { R-square }\end{array}$ & $C(p)$ & $P>F$ \\
\hline Seed number target (Snt) & $\begin{array}{l}\text { Div } \\
\text { Pop }\end{array}$ & $\begin{array}{l}1 \\
2\end{array}$ & $\begin{array}{l}0.5456 \\
0.0519\end{array}$ & $\begin{array}{l}0.5456 \\
0.5975\end{array}$ & $\begin{array}{l}4.4822 \\
3.0000\end{array}$ & $\begin{array}{l}<.0001^{\text {hs }} \\
0.0729^{\text {ns }}\end{array}$ \\
\hline \multicolumn{7}{|c|}{ (4) Snt $=--5346+14096 \operatorname{div}-14.34766 \mathrm{pop}\left(R^{2}=0.5456\right)$} \\
\hline Seed weight target (SWt) & $\begin{array}{l}\text { Div } \\
\text { Pop }\end{array}$ & $\begin{array}{l}1 \\
2\end{array}$ & $\begin{array}{l}0.8930 \\
0.0202\end{array}$ & $\begin{array}{l}0.8930 \\
0.9132\end{array}$ & $\begin{array}{l}7.3005 \\
3.0000\end{array}$ & $\begin{array}{l}<.0001^{\mathrm{hs}} \\
0.0184^{\mathrm{s}}\end{array}$ \\
\hline \multicolumn{7}{|c|}{ (5) $S W t=-14166+309804$ div-43.19979 $\left(R^{2}=0.9132\right)$} \\
\hline Branch Number (Bn) & $\begin{array}{l}\text { Div } \\
\text { Pop }\end{array}$ & $\begin{array}{l}1 \\
2\end{array}$ & $\begin{array}{l}0.6110 \\
0.0075\end{array}$ & $\begin{array}{l}0.6110 \\
0.6185\end{array}$ & $\begin{array}{l}1.5308 \\
3.0000\end{array}$ & $\begin{array}{l}<.0001^{\mathrm{hs}} \\
0.4725^{\mathrm{ns}}\end{array}$ \\
\hline \multicolumn{7}{|c|}{ (6) $\mathrm{Bn}=0.8655+82.4138 \operatorname{div}\left(\mathrm{R}^{2}=0.6110\right)$} \\
\hline BA total (BAp) & Pop & 1 & 0.4265 & 0.4265 & 4.7242 & $<.0001^{\text {hs }}$ \\
\hline \multicolumn{7}{|c|}{ (7) $\mathrm{BAp}=4884.05617-7.24010 \mathrm{pop}\left(\mathrm{R}^{2}=0.4961\right)$} \\
\hline $\mathrm{BA}^{\prime}$ total $^{-1}(\mathrm{BAt})$ & $\begin{array}{l}\text { Pop } \\
\text { Div }\end{array}$ & $\begin{array}{l}1 \\
2\end{array}$ & $\begin{array}{l}0.2115 \\
0.1219\end{array}$ & $\begin{array}{l}0.2115 \\
0.3334\end{array}$ & $\begin{array}{l}5.9371 \\
3.0000\end{array}$ & $\begin{array}{l}0.0106^{\mathrm{hs}} \\
0.0349^{\mathrm{s}}\end{array}$ \\
\hline \multicolumn{7}{|c|}{ (8) $\quad B A t=367.21288+130.3785 \operatorname{div}+0.54898 p o p\left(R^{2}=0.3334\right)$} \\
\hline \multirow[t]{2}{*}{$\begin{array}{l}\text { Leaf Chlorofil Indeks } \\
\text { (LCI) }\end{array}$} & Div & 1 & 0.2328 & 0.2328 & 13.4940 & $0.0011^{\mathrm{hs}}$ \\
\hline & \multicolumn{6}{|c|}{ (9) $\quad \mathrm{LCl}=33.46571+7.4405$ div-0.0241pop $\left(\mathrm{R}^{2}=0.4755\right)$} \\
\hline Canopy width (CWd) & $\begin{array}{l}\text { Pop } \\
\text { Div }\end{array}$ & $\begin{array}{l}1 \\
2\end{array}$ & $\begin{array}{l}0.3150 \\
0.0140\end{array}$ & $\begin{array}{l}0.3150 \\
0.3290\end{array}$ & $\begin{array}{l}1.5638 \\
3.0000\end{array}$ & $\begin{array}{l}0.0013^{\mathrm{hs}} \\
0.4592^{\mathrm{ns}}\end{array}$ \\
\hline (10) $\quad C W d=13.87350-0$. & 450pop (R & $0.3150)$ & & & & \\
\hline
\end{tabular}

Note: $n s=$ non significant, $s=$ significant, and $h s=$ highly significant at level $\alpha=0.05$. pop = population, div = diversity.

Multiple regression analysis with stepwise procedure showed that population and diversity simultaneously had significant effect $(p<0.05)$ on leaf chlorophyll index, seed 
number target ${ }^{-1}$ and seed weight target $^{-1}$, as well as BA (Table 3). Linear relationship optimum model between plant characters, population and diversity can be seen in eq. 4-10.

In partial, diversity had significant effect on the branches number and seed weight number ${ }^{-1}$, while population had significant effect on the BA total and canopy width (Table 3 ). They also had a significant effect on seed weight target $^{-1}$, BA total ${ }^{-1}$, and leaf chlorophyll index. In general, the contributions of diversity (55-89\%) were higher than the population (21$42 \%$ ) on the character of the nutmeg plants. Seed number target ${ }^{-1}$, and seed weight target ${ }^{-1}$ increased by the maximum population and then decreased in further population increase (equation 11 and 12). At the maximum population ( op $_{\max } 192$ trees ha ${ }^{-1}$ ), 10.691 seeds weight target ${ }^{-1}$ were obtained (equation 11) and at pop $_{\max }$ of 194 trees ha ${ }^{-1}$, the obtained seeds weight target ${ }^{-1}$ were $32.26 \mathrm{~kg}$ (equation 12):

Number of acorns ${ }^{-1}, \hat{Y}=-17397+291.98550 p o p-0.75879 p o p^{2}\left(R^{2}=0.5975 ; P>F=<.0001\right)$ Seed weight ${ }^{-1}, \hat{Y}=-53175+888.20600$ pop -2.30863 pop $^{2}\left(R^{2}=0.9132 ; P>F=<.0001\right)$

Makinde (2009) reported that the population density has a significant effect on the character of jute plant height and environment humidity. Population rises up to a certain level can increase production (He, 2005; Di Zhang, 2015), but when the density increases in the average growth of the plants per population, there would be intraspesific competition (Makinde, 2009). Furthermore, Michelle et al., in Makinde (2009) stated that by nature, the competition between plants in a population can be ignored (not significant) until the population reaches a density threshold and the resource capability becomes limited. Nutmeg crop production on a population of 100 plants $^{-1} a^{-1}$ was lower than on a population of 200 plants $\mathrm{ha}^{-1}$. Gradually, the seed number target ${ }^{-1}$, and the seed weight target ${ }^{-1}$ decreased $^{-1}$ along with the increase of population (equations 11-12), indicating the existence of interspecific competition. Oksanen (2006) and Shaukat (2009) stated that interspecific competition has very significant effect on most agronomic characteristics of plants.

Micro climate characteristics of agroforestry systems nutmeg plantation. Population and diversity had very significant effect on the component of microclimate agroforestry systems of nutmeg plantation (Table 4). Plantation with population of 200 plants ha ${ }^{-1}$ with diversity of $1.38\left(\mathrm{Agf}_{2}\right)$ showed relatively low temperature, relative humidity, light net, light absorption, and RUE which were significantly different from the population of 100 plants ha-1 with diversity of $0.78\left(\mathrm{Agf}_{1)}\right.$ but higher and significantly different when compared with the population of 300 plants ha ${ }^{-1}$ with diversity of $0.82\left(\mathrm{Agf}_{3)}(\right.$ Table 5$)$.

Table 4 - Analysis of variance of population and diversity effect on the microclimate of nutmeg plantation using agroforestry system

\begin{tabular}{lllllll}
\hline Variable & Mean & $\begin{array}{l}\text { Variation } \\
\text { Coefficient }\end{array}$ & $\begin{array}{l}\text { Std } \\
\text { Dev }\end{array}$ & Minimum & Maximum & $\mathrm{P}>\mathrm{F}$ \\
\hline Temperature $\left({ }^{\circ} \mathrm{C}\right)$ & 30.47767 & 0.596 & 0.32736 & 30.01000 & 31.33000 & $0.0002^{\mathrm{hs}}$ \\
Relative Humidity $(\%)$ & 73.70633 & 0.711 & 4.86750 & 67.26000 & 79.97000 & $<.0001^{\mathrm{hs}}$ \\
Intercept radiation $\left(\mathrm{I}_{\mathrm{i}}, \mathrm{Wm}^{-2}\right)$ & 4.221667 & 1.415 & 0.08429 & 4.01000 & 4.34000 & $0.0001^{\mathrm{hs}}$ \\
Radiation nett $\left(\mathrm{In}_{\mathrm{n}}, \mathrm{Wm}^{-2}\right)$ & 16958 & 12.71543 & 3076 & 10116 & 22044 & $<.0001^{\mathrm{hs}}$ \\
RUE $\left(\mathrm{g} / \mathrm{W} \mathrm{m}^{-2}\right)$ & 948.2013 & 1.948 & 28.668 & 908.98 & 1021.00 & $<.0001^{\mathrm{hs}}$ \\
\hline
\end{tabular}

Note: $h s=$ highly significant.

The results of multiple regression analysis using stepwise procedure showed that the population had very significant effect $(p<0.0001)$ on the total radiation, intercept radiation, temperature, humidity, and RUE with contributions ranging from $52-99 \%$, whereas the effect of diversity on the four micro-climate components were not significant $(p>0.05)$ (Table 6). Optimum model of linear relationship between plant characters components with population and diversity can be seen in equation 13-17.

Agroforestry system is a land usage system which is most appropriate in supporting the growth of plantation crops with other crops simultaneously (De Zoysa, et al., 2014), with variations in population and diversity. Variations in population and diversity of agroforestry by Cannell (1991) can be set in five canopy layers, and each layer provides a variation on the 
character of the plants and microclimate. At the optimum population and diversity $\left(\mathrm{Agf}_{2}\right)$, it is known that the radiation nett, intercept radiation, temperature and relative humidity were significantly different from the two other plantations $\left(\mathrm{Agf}_{1}\right.$ and $\left.\mathrm{Agf}_{3}\right)$. The effect of population and diversity to intercept radiation, temperature and relative humidity in the plantation system $\mathrm{Agf}_{2}$ iwas optimum compared to the character of nutmeg plants, especially the number of fruit and seed weight. Results of research on the character of nutmeg crop in the plantation with different population and diversity showed that most of the plant characteristics responded the increasing number of population in each nutmeg plantation.

Table 5 - The effect of agroforestry system (density and diversity) on the temperature, relative humidity, intercept radiation, and total radiation

\begin{tabular}{llllll}
\hline $\begin{array}{l}\text { Agroforestry } \\
\text { system }\end{array}$ & $\begin{array}{l}\text { Temperature } \\
\left({ }^{0} \mathrm{C}\right)\end{array}$ & $\begin{array}{l}\text { Relative } \\
\text { Humadity }(\%)\end{array}$ & $\begin{array}{l}\text { Intercept Radiation } \\
\left(\mathrm{Wm}^{-2}\right)\end{array}$ & $\begin{array}{l}\text { Total Radiation } \\
\left(\mathrm{Wm}^{-2}\right)\end{array}$ & $\begin{array}{l}\text { RUE } \\
\left(\mathrm{g} / \mathrm{Wm} \mathrm{m}^{-2}\right)\end{array}$ \\
\hline $\mathrm{Agf}_{1}$ & $30.85 \mathrm{a}$ & $67.96 \mathrm{c}$ & $4.15 \mathrm{c}$ & $1421 \mathrm{c}$ & $976.41 \mathrm{a}$ \\
$\mathrm{Agf}_{2}$ & $30.41 \mathrm{~b}$ & $73.53 \mathrm{~b}$ & $4.23 \mathrm{~b}$ & $1695 \mathrm{~b}$ & $944.25 \mathrm{~b}$ \\
$\mathrm{Agf}_{3}$ & $30.17 \mathrm{c}$ & $79.63 \mathrm{a}$ & $4.29 \mathrm{a}$ & $1971 \mathrm{a}$ & $923.94 \mathrm{c}$ \\
\hline
\end{tabular}

Notes: Means with the same letters within columns indicate significant differences at the Duncan 0.05 Agf $_{1}=$ plantation with agroforestriy system with population of 100 trees ha ${ }^{-1}$ with diversity of 0.78 , $\mathrm{Agf}_{2}==$ plantation with agroforestriy system with population of 200 trees ha ${ }^{-1}$ with diversity of 1.38, $\mathrm{Agf}_{3}==$ plantation with agroforestriy system with population of 300 tress ha ${ }^{-1}$ with diversity of 0.82 .

Table 6 - Stepwise procedure summary and the optimum model of microclimate based on agroforestry system

\begin{tabular}{|c|c|c|c|c|c|c|}
\hline Micro climate & $\begin{array}{l}\text { Variable } \\
\text { entered }\end{array}$ & $\begin{array}{l}\text { Number } \\
\text { Variabel In }\end{array}$ & $\begin{array}{l}\text { Partial } \\
\text { R-square }\end{array}$ & $\begin{array}{l}\text { Model } \\
\text { R-square }\end{array}$ & $C(p)$ & $\mathrm{P}>\mathrm{F}$ \\
\hline Total Radiation $\left(\mathrm{I}_{\mathrm{t}}\right)$ & Pop & 1 & 0.5523 & 0.5523 & 1.0002 & $<.0001^{\mathrm{hs}}$ \\
\hline \multicolumn{7}{|c|}{ (13) $\quad \operatorname{Tr}=11453+27.5255 \mathrm{pop}\left(\mathrm{R}^{2}=0.5523\right)$} \\
\hline $\begin{array}{l}\text { Intercept Radiation }\left(l_{i}\right) \\
(14) \quad \text { Ir }=4.07467+0 . .0\end{array}$ & (14) $\quad \mathrm{Ir}=4.07467+0 . .00073 \mathrm{pop}\left(\mathrm{R}^{2}=0.5244\right)$ & $\begin{array}{l}1 \\
.5244)\end{array}$ & 0.5244 & 0.5244 & 1.0778 & $<.0001^{\text {hs }}$ \\
\hline Temperature $(\mathrm{T})$ & Pop & 1 & 0.7461 & 0.7461 & 3.5747 & $<.0001^{\mathrm{ns}}$ \\
\hline \multicolumn{7}{|c|}{ (15) $\quad T=31.32550-.00337 \mathrm{pop}\left(\mathrm{R}^{2}=0.7461\right)$} \\
\hline Relative Humidity (RH) & Pop & 1 & 0.9900 & 0.9900 & 3.0487 & $<.0001^{\mathrm{hs}}$ \\
\hline \multicolumn{7}{|c|}{ (16) $\mathrm{RH}=62.48448+0.05841 \mathrm{pop}\left(\mathrm{R}^{2}=0.9900\right)$} \\
\hline Radiation use efficiency & Pop & 1 & 0.5776 & 0.5776 & 1.6427 & $<.0001^{\text {hs }}$ \\
\hline (RUE) & Div & 2 & 0.0098 & 0.5874 & 3.0000 & $0.4297^{\mathrm{ns}}$ \\
\hline (17) $\quad Y=1010.4119-10$ & 164div-0.26 & $3 p o p\left(R^{2}=0\right.$ & $74 ; P>F<.0$ & & & \\
\hline
\end{tabular}

Note: $n s=$ non significant and $h s=$ highly significant at level $\alpha=0.05$. pop $=$ population, div $=$ diversity.

Micro climate condition of each plant is also influenced by the interaction between the number and type of plants (Salazar et al., 2010). The effect is related to transpiration and chemical reactions, as well as the evaporation plant (He, 2005). C3 plant stomata are very sensitive to the relative humidity and contribute to the rate of photosynthesis and transpiration ratio (Da Matta in Pezzopene 2011; Pyakurel, 2014). Furthermore, Makinde (2009), Wyszomirski and Weiner (2009) state that the same species have similar ecological requirements so that the dependence of plants on the availability of space is very important and lack of it will lead to competition. Plantation $\mathrm{AgF}_{2}$ has higher diversity, number and weight of nutmeg crop seeds than the two other plantations. The diversity of plant characters can be positive for the plants (Pretzsch, 2014), influence the chemical litter, litter biomass, temperature and soil moisture (Eviner and Chapin, 2003; Eviner, 2004; Barbier et al., 2008). Various considerations in productivity improvements are expected to reach the standard maximum number of trees per hectare (Khorshidi, et al., 2009; Chalmers, 2014). Production of nutmeg in the population of 200 plants ha $^{-1}$ and diversity of 1.38 is assumed to be better than the other two populations.

Correlation coefficient ( $r$ ) between populations and diversity with the microclimate and plant components are presented in Table 7 . The population was correlated with total radiation $(0.74)$, radiation absorption $(0.72)$, temperature $(-0.86)$, relative humidity $(0.99)$, BA 
total (0.65), DBH total (0.51), and canopy width (0.56). While the diversity of plants was closely correlated with seed number target ${ }^{-1}(0.89)$, seed weight target $^{-1}(0.94)$, and branches number (0.78). Seed number target ${ }^{-1}$ was closely correlated with branches number (0.78) and leaf chlorophyll index (0.58). Seed weight target ${ }^{-1}$ was closely correlated with the total radiation (-0.69), intercept radiation $(-0.67)$, and leaf chlorophyll index $(0.63)$. It is also known that there was a real or very real correlation between the characters of the plants, namely the number of branches with leaf chlorophyll index (0.52) and weight of 100 seeds (0.78). The weight of 100 seeds was also significantly correlated with radiation nett $(0.69)$ and intercept radiation (0.67). Furthermore, temperature and $\mathrm{RH}$ was significantly correlated with $\mathrm{BA}$ total, $\mathrm{DBH}$ target, $\mathrm{DBH}$ total, and canopy width. The canopy width was also significantly correlated with total light and light absorption. The BA total was significantly correlated with the total radiation, temperature, and humidity. This fact explains that the components of microclimate and plant characters were correlated with population and diversity.

Table 7 - Coeffient correlation between plant morphological characteristics and microclimate based on population and diversity of nutmeg plantation

\begin{tabular}{|c|c|c|c|c|c|c|c|c|}
\hline & Population & Diversity & $\mathrm{Bn}$ & $\mathrm{I}_{\mathrm{t}}$ & $\mathrm{l}_{\mathrm{i}}$ & $\mathrm{T}$ & RH & $\mathrm{LCl}$ \\
\hline Population & 1.0000 & $0.0596^{\mathrm{ns}}$ & $0.0398^{\mathrm{ns}}$ & $0.7431^{\mathrm{s}}$ & $0.7242^{\mathrm{s}}$ & $-0.8638^{\text {hs }}$ & $0.9950^{\text {hs }}$ & $-0.4630^{\mathrm{ns}}$ \\
\hline Snt & $-0.1739^{\mathrm{ns}}$ & $0.8975^{\mathrm{hs}}$ & $0.7874^{\mathrm{hs}}$ & $-0.5073^{\mathrm{ns}}$ & $-0.2774^{\mathrm{ns}}$ & $0.0490^{\mathrm{ns}}$ & $-0.2080^{\mathrm{ns}}$ & $0.5968^{\mathrm{s}}$ \\
\hline SWt & $-0.0857^{\mathrm{ns}}$ & $0.9449^{\mathrm{hs}}$ & $0.3738^{n s}$ & $-0.6959^{s}$ & $-0.6755^{s}$ & $-0.0522^{\mathrm{ns}}$ & $-0.1154^{\mathrm{ns}}$ & $0.6321^{\mathrm{s}}$ \\
\hline $\mathrm{LCl}$ & $-0.4630^{\mathrm{ns}}$ & $0.4825^{\mathrm{ns}}$ & $0.5254^{\mathrm{s}}$ & $-0.3878^{n s}$ & $-0.3595^{\mathrm{ns}}$ & $0.2964^{\mathrm{ns}}$ & $-0.4780^{\mathrm{ns}}$ & 1.0000 \\
\hline LAI & $-0.2968^{\mathrm{ns}}$ & $0.4314^{\mathrm{ns}}$ & $0.4056^{\mathrm{ns}}$ & $-0.2310^{\mathrm{ns}}$ & $0.1976^{\mathrm{ns}}$ & $0.1492^{\mathrm{ns}}$ & $-0.3029^{n s}$ & $0.4812^{n s}$ \\
\hline Bap & $-0.6531^{\mathrm{s}}$ & $-0.3021^{n s}$ & $-0.1812^{n s}$ & $0.7958^{\mathrm{hs}}$ & $-0.3199^{n s}$ & $0.6279^{\mathrm{s}}$ & $-0.6617^{\mathrm{s}}$ & $0.1683^{\mathrm{ns}}$ \\
\hline Bat & $0.4598^{\mathrm{ns}}$ & $0.3759^{\mathrm{ns}}$ & $-0.2674^{\mathrm{ns}}$ & $-0.3232^{n s}$ & $0.8112^{\mathrm{ns}}$ & $-0.5596^{\mathrm{s}}$ & $0.4590^{\mathrm{ns}}$ & $0.2418^{\mathrm{ns}}$ \\
\hline $\mathrm{DBHt}$ & $-0.4924^{n s}$ & $-0.1254^{\mathrm{ns}}$ & $-0.1417^{\mathrm{ns}}$ & $-0.3294^{n s}$ & $-0.3556^{n s}$ & $0.5994^{\mathrm{s}}$ & $-0.54518^{s}$ & $0.1312^{\mathrm{ns}}$ \\
\hline DBHp & $-0.5137^{\mathrm{s}}$ & $-0.0976^{\mathrm{ns}}$ & $-0.1286^{\mathrm{ns}}$ & $-0.3578^{n s}$ & $0.3264^{\mathrm{ns}}$ & $0.5854^{\mathrm{s}}$ & $-0.52470^{s}$ & $0.1291^{\mathrm{ns}}$ \\
\hline she & $-0.1910^{\mathrm{ns}}$ & $0.2248^{\mathrm{ns}}$ & $0.7816^{\mathrm{hs}}$ & $0.6957^{\mathrm{s}}$ & $-0.6755^{\mathrm{s}}$ & $0.2374^{\mathrm{ns}}$ & $-0.2085^{\mathrm{ns}}$ & $0.2592^{\mathrm{ns}}$ \\
\hline CWd & $-0.5612^{s}$ & $0.1516^{\mathrm{ns}}$ & $-0.0739^{n s}$ & $-0.5354^{\mathrm{s}}$ & $-0.5114^{s}$ & $0.5216^{\mathrm{s}}$ & $-0.5765^{\mathrm{s}}$ & $0.2249^{\mathrm{ns}}$ \\
\hline $\mathrm{Bn}$ & $-0.0398^{n s}$ & $0.7817^{\mathrm{hs}}$ & 1.0000 & $0.1531^{\mathrm{ns}}$ & $-0.1265^{\mathrm{ns}}$ & $-0.0390^{n s}$ & $-0.0639^{n s}$ & $0.5254^{\mathrm{s}}$ \\
\hline $\mathrm{Ph}$ & $-0.3104^{n s}$ & $0.0347^{\mathrm{ns}}$ & $-0.0218^{n s}$ & $-0.0366^{\mathrm{ns}}$ & $-0.0044^{\mathrm{ns}}$ & $0.2957^{\mathrm{ns}}$ & $-0.3209^{n s}$ & $0.1918^{\mathrm{ns}}$ \\
\hline
\end{tabular}

Note: $n s=$ non significant, $s=$ significant, and $h s=$ highly significant at level $\alpha=0.05 . B n=$ branch number, $I_{t}=$ total radiation, $I_{i}=$ intercept radiation, $T=$ temperature, $R H=$ relative humadity, $L C l=$ Leaf chlorophyll index, Snt $=$ Seed number target $t^{-1}$ (tree), SWt $=$ Seed weight target ${ }^{-1}$ (tree) $D B H p=D B H$ total, DBHt $=D B H$ target (tree), $B A t=B A$ target (pohon), BAp =BA total, LAI = Leaf area index, CWd = Canopy width, $P h=$ plant heigh.

\section{CONCLUSION}

From the research has been conducted, it can be concluded that the variation of population and diversity in the agroforestry systems of nutmeg plantations affect the whole characteristics of nutmeg plant observed. Based on the results obtained in all three agroforestry systems, it is known that $\mathrm{AgF}_{2}$ with a population of 200 plants ha ${ }^{-1}$ gives more suitable growth space and microclimate for the nutmeg crop so that it can increase the number and weight of seeds compared to the plantation with higher population $\left(\mathrm{Agf}_{3}\right)$ or lower population $\left(\mathrm{Agf}_{1}\right)$.

Variations of population in the agroforestry system of nutmeg plantations determine the microclimate conditions. The results of analysis showed a significant relationship between the population and the characteristics of the microclimate. Furthermore, the microclimate affects the characteristics of the nutmeg crop. This research suggests that nutmeg plants tend to be shade-tolerant. Therefore, the nutmeg crop is suitable to be planted using agroforestry systems with optimum range of population and diversity.

Nutmeg plantation population correlates with all characteristics of the microclimate, and characteristics of the nutmeg crop for total basal area, total diameter at breast height (DBH), and canopy width. The diversity of nutmeg plantations was closely correlated with the characters of the plants, especially the seed number target ${ }^{-1}$ and sedd weight target ${ }^{-1}$ as well as the branches number. Thus, the characteristics of the plant and the microclimate respond the increase on the number of population in each nutmeg plantation. The effort in improving 
nutmeg crop production requires a standard maximum number of trees per hectare. Based on the results of research on the agroforestry system of nutmeg plantation in Ternate Island, it is assumed that population of 200 plants ha $^{-1}$ and diversity of 1.38 is better than the other populations.

\section{REFERENCES}

1. Abdul, M., and Tjokrodiningrat, S. 2013. Kajian dan pilot pengembangan tanaman pala di Kabupaten Wakatobi. Pemda Kabupaten Wakatobi-CV. Tirta Arta Consulindo (p.60). not publication.

2. Arrijani. 2008. Struktur dan komposisi vegetasi zona Montana Taman Nasional Gunung Gede Pangrango. Biodiversitas (9). 7 p.

3. Ariapour, R. and S. H. Afrougheh. 2008. Effect of planting density on productivity of six species of annual medics. International Journal of Agriculture \& Biology. 8 (10): 701-704.

4. Awal, M.A. and W.I. Wan-Ishak. 2008. Measurement of oil palm LAI by manual and LAI2000 method. Asian J. Sci. Res. 1 (1): 49-56.

5. Barbier, S., F. Gosselin, and P. Balandier. 2008. Influence of tree species on understory vegetation diversity and mechanisms involved: A critical review for temperate and boreal forests. For. Ecol. Manag. 254: 1-15.

6. Béland M., J.M. Lussier, Y. Bergeron, M.H. Longpre, and M. Béland. 2003. Structure, spatial distribution and competition in mixed jack pine (Pinus banksiana) stands on clay soils of eastern Canada. Ann. For. Sci. 60:609-617.

7. Belote, R. T., S. Prisley, R.H. Jones, M. Fitzpatrick, K. de Beurs. 2011. Forest productivity and tree diversity relationships depend on ecological context within midAtlantic and Appalachian forests (USA). Forecol. 01 (010): 1-10.

8. Berger U., C. Piou, K. Schiffers, V,Grimm. 2007. Competition among plants: Concepts, individual-based modeling approaches, and a proposal for a future research strategy. Perspection in plant ecology, evolution and systematics. 9: 121-135.

9. Bustaman, S. 2007. Prospek dan strategi pengembangan pala di Maluku. Perspektif 6 (2): 68-74.

10. Cannell, M.G.R. 1991. Plant management in agroforestry, in M.A. Avery, M.G.R. Cannell, C.K. Ong (ed), Biophysical research for Asian agroforestry. p: 66-72.

11. Chalmers D.J. 2014. The prospects for improved productivity of stone and pome fruit crops from improved plant management. Irrigation Research Institute Tatura. Victoria. $\mathrm{p}$ : 109-126.

12. Cinar, I.B. and Tug, G.N., 2015. The morphology, ecology, and conservation status of the local endemic species Salsola grandis. Ekoloji 24 (96): 41-47.

13. Damgaard, C., 2011. Measuring competition in plant communities where it is difficult to distinguish individual plants. IAEES. Computational ecol. and software. 1 (3): 125-137.

14. De Zoysa and M. Inoue. 2014. Climate change impacts, agroforestry adaptation and policy environment in Sri Lanka. Open J. of Forestry. 4:439-456.

15. Ditzer, T., Glauner, R., Forster, M., Kohler, P., Huth, A., 2000. The process-based stand growth model Formix 3-Q applied in a GIS environment for growth and yield analysis in a tropical rain forest. Tree Physiology. 20: 367-381.

16. Di Zhang, Q, Zhi Jia, R., C.Meng, Wen Ti, C., Ling Wang, Y. 2015. Diversity and population structure of a dominant deciduous tree based on morphological and genetic data. AOB Plants. 7 (103): 1-13

17. Elzinga C. L., D.W. Salzer, J. W. Willoughby. 1998. Measuring and monitoring plant populations. Bureau of Land Management. National Business Center. Colorado. $497 \mathrm{pp}$.

18. Enquist B.J., West G.B., Brown J.H., 2009. Extension and evaluations of a general quantitave theory of forest structure and dynamics. PNAS 106 (17): 7046-7051.

19. Eviner, V. T. 2004. Plant traits that influence ecosystem processes vary independently among species. Ecol. 85: 2215-2229.

20. Eviner, V. T. and F. S. Chapin III. 2003. Functional matrix: A conceptual framework for predicting multiple plant effects on ecosystem processes. Ann. Rev. Ecol. Evol. Syst. 34: 455-485. 
21. Fangliang, H. and R.P. Duncan. 2000. Density-dependent effects on tree survival in an old-growth Douglas fir forest. J. Ecol. 88: 676-688.

22. Futakuchi, K. 2007. Quantification of competitive interference by neighboring plants in a crop population. African Crop Sci. Conf. Proc. 8: 233-236.

23. Hadad, E.A. 2009. Dokumen Pengusulan Pelepasan Pala Ternate-1, Tidore-1, dan Tobelo-1, Maluku Utara. Balitro. Bogor. 33 pp.

24. Hadad E.A, E., Randriani, C. Firman, and T. Sugandi. 2006. Budidaya tanaman pala. Balai Penelitian Tanaman Rempah dan Aneka Tanaman Industri Parungkuda. 35 pp.

25. Hadad E.A., 1991. Keragaan plasma nutfah pala di propinsi Maluku hasil eksplorasi dan pelestarian 1990/1991. Makalah pada seminar plasma nutfah tanaman hortikultura, industri dan pangan. Puslitbangtan. September 1991 Bogor: 12.

26. He J.S., S.Kelly, W., Bellin, B. Schmid, F.A. Bazzaz. 2005. Density may alter diversityproductivity relationship in experimental plant communities. Basic and Applied Ecol. (6): 505-517.

27. IPGRI. 1980. Tropical Fruits Descriptor. IPGRI. Southeast Asia Regional Committee. Rome. Italy. $14 \mathrm{pp}$.

28. Jin C. C., F. T. Maestre, Sa Xiao, J. Weiner, You-Shi Wang, Zheng-Hu Duan, and G. Wang. 2008. Balance between facilitation and resource competition determines biomassdensity relationships in plant populations. Ecol. let. 11: 1189-1197.

29. Jin C.C., J. Weiner, T. Fernando Maestre, Sa Xiao, J. Weiner, You-Shi Wang, Qi Li, JianLi Yuan, Lu-Qiang Zhao, Zheng-Wei Ren, and Gang Wang. 2009. Positive interactions can increase size inequality in plant populations. J. of Ecol. 97: 1401-1407.

30. Kementrian Negara Lingkungan Hidup. 2004. Keputusan menteri negara lingkungan hidup nomor 201 tahun 2004 tentang kriteria baku dan pedoman penentuan kerusakan mangrove. Kementerian Negara Lingkungan Hidup RI. 11 pp.

31. Kohli R.K., D.R.Batish, S.Jose, H.P. Singh. 2008. Ecological basis of agroforestry. CRC Press. Boca Raton. 400 pp.

32. Khorshidi, J., M.F. Tabatabaei, R. Omidbaigi, and F. Sefidkon. 2009. The effect of different densities of planting on morphological characters, yield, and yield components of fennel (Foeniculum vulgare Mill.cv.Soroksary. J.of Agri. Sci. 1 (2): 66-73.

33. Liu, Z.A., J.P. Yang, and Z.C. Yang. 2012. Using a chlorophyll meter to estimate tea leaf chlorophyll and nitrogen contents. J. of Soil Sci. \& Plant Nutrition. 12 (2): 339-348.

34. Makinde, S.C. Olubunmi, Oluwole, O. Surukite, Ojekale, B. Anthony, Olufeyimi, and S. Rachael. 2009. Effects of intrapopulation competition on morphological and agronomic characters of Jute plant (Corchorus olitorius L.). African J. of Biotech. 8 (10): 2195-2201.

35. Marcelle, G. B. 1995. Production, handling and processing of nutmeg and mace and their culinary uses. FAO UN. 55 pp.

36. Marzuki, I., Hadad E.A., M. Syukur, dan M. Assegaf. 2006. Potensi dan pengembangan pala di Maluku Utara. Balittro. Bogor. $57 \mathrm{pp}$.

37. Michon, G., F. Mary, and J. Bompard. 1986. Multistoried agroforestry garden system in West Sumatra, Indonesia. Agroforestry Systems. 4: 315-338.

38. Mitchell, K. 2010. Quantitative Analysis by the point-centered quarter method. Dep. of Math. \& Comp. Sci. Hobart \& William Smith Colleges. Geneva, NY. arXiv:1010.3303v1 [q-bio.QM] 16 Oct. 34 pp.

39. Onrizal, 2009. Silvika. Pertumbuhan pohon kaitannya dengan tanah, air dan iklim. Bahan ajar. Dept. Kehutanan. Fakultas Pertanian. USU. 55 pp.

40. Ong. C.K. 1991. Interaction of light, water, and nutrients in agroforestry systems. in M.A. Avery, M.G.R. Cannell, C.K. Ong (ed), Biophysical research for Asian agroforestry p: 107-124.

41. Oksanen, L., M.Sammul, and M. Ma"gi. 2006. On the indices of plant-plant competition and their pitfalls. Oikos. 112: 149-155.

42. Poorter, L. and F, Bongers. 2006. Leaf traits are good predictors of plant performance across 53 rain forest species. J. Ecol. 87 (7): $1733-1743$.

43. Pretzsch, H. 2009. Forest dynamics, growth and yield: from measurement to model. Springer-Verlag Berlin Heidelberg. $671 \mathrm{pp}$. 
44. Pretzsch, H. 2014. Canopy space filling and tree crown morphology in mixed-species stands compared with monocultures. http://dx.doi.org/10.1016/j.foreco.2013.04.027.

45. Pyakurel, A. and J.R. Wang. 2014. Leaf morphological and stomatal variations in paper birch populations along environmental gradients in Canada. American J. of Plant Sci. 5:1508-1520.

46. Rodriguez-Garcia E, C. Ordóћez, F. Bravo. 2011. Effects of shrub and canopy cover on the relative growth rate of Pinus pinaster Ait. Seedlings of different sizes. Ann. Of Forest Scien.Springer. DOI 10.1007/s13595-011-0039-5.

47. Rudorff, B.F.T., C. L. Mulchi, C.S. T. Daughtry, and E.H. Lee. 1996. Growth, radiation use efficiency, and canopy reflectance of wheat and corn grown under elevated ozone and carbon dioxide atmospheres. Elsevier Sci. Inc. 55:163-173.

48. Salazar, 1 S., L. E Sanchez, P. Galindo and I. Santa-Regina, 2010. Above-ground tree biomass equations and nutrient pools for a paraclimax chestnut stand and for a climax oak stand in the Sierra de Francia Mountains,Salamanca, Spain. Scientific Research and Essays Vol. 5(11), pp. 1294-1301.

49. [SAS] Institute. 2004. SAS/STAT User's Guide, release 9.1.3 edition. SAS Institute Inc. Cary, NC.

50. Sarle, S.W. and J.H. Goodninght. 1982. The R-square procedure. In A.A. Ray (Ed.), SAS User's Guide. Stat. SAS Inst. Inc. Cary, NC. p:86-91.

51. Shaukat, S.S., W. Ahmed, M.A. Khan, and A. Shahzad. 2009. Intraspecific competition and aggregation in a population of Solanum forskalii Dunal in a semiarid habitat: Impact on reproductive output, growth and phenolic contents. Pak. J. Bot. 41(6): 2751-2763.

52. Sumantra, I.K., S. Ashari, T. Wardiyati, dan A. Suryanto. 2012. Diversity of shade trees and their influence on the microclimate of agro-ecosystem and fruit production of gulapasir salak (Salacca Zalacca var. Amboinensis) fruit. Inter. J. of Basic \& App. Sci. IJBAS-IJNES 12 (06): 214-221.

53. Sutaryo. D. 2009. Perhitungan biomassa; sebuah pengantar untuk studi karbon dan perdagangan karbon. Wetlands Internasional Indonesia Programme. 48p.

54. Thankamani, C.K., K. Sivaraman, K. Kandiannan, and K.V. Peter. 1994. Agronomy of tree spices (clove, nutmeg, cinnamon and allspice) - a review. Journal of Spices \& Aromatic Crops. 3(2): 105-123.

55. Tjokrodiningrat, S., A.M. Mandea, A. Madiki, 2013. Morhological characteristics and agroecological based variability of nutmeg (Myristica spp) in North Moluccas. J. Cannarium 11(1): $1-5$.

56. Tjokrodiningrat, S., R. Hadun, S. Sudjud, and Abdul-Madiki. 2011. Laporan forum diskusi mengembalikan kejayaan rempah Maluku Utara sebagai provinsi rempah menyongsong sail Indonesia di Morotai 2012. Pemda Prov. Malut-PT. Bunga Tani-Ternate Omdi Enter. Ternate, 22 Feb. 2011. 28 pp.

57. Umrani, R., and C.K. Jain. 2010. Agroforestry systems and practices. Oxford Book Company. 307 pp.

58. Wardiana, E., E. Randriani, and C. Tresniawati. 2008. Seleksi beberapa karakter penting 15 aksesi tanaman pala (Myristica fragrans Houtt.) di kebun percobaan Cicurug, Sukabumi. Zuriat. 19(1): 116-129.

59. Weiner, J., Stoll, P., Muller-Landau, H., Jasentuliyana, A., 2001. The effects of density, spatial pattern, and competitive symmetry on size variation in sumulated plant populations. Am. Nat. 158: 438-450.

60. Wyxzomirski, T. and J.Weiner. 2009. Variation in local density results in a positive correlation between plant neighbor sizes. Am. Nat. 2009 173: 705-708.

61. Wright, S.J. 2002. Plant diversity in tropical forests: a review of mechanisms of species coexistence. Oecologia. 130: 1-14.

62. Xu, F., W. Guo, W. Xu, Y. Wei, and R. Wang. 2009. Leaf morphology correlates with water and light availability: What consequences for simple and compound leaves?. Nat. sci. Foundation of China. 19: 1789-1798. 